\title{
Front Matter: Volume 8398
}

, "Front Matter: Volume 8398," Proc. SPIE 8398, Optical Pattern Recognition XXIII, 839801 (23 April 2012); doi: 10.1117/12.964995

EPIE Event: SPIE Defense, Security, and Sensing, 2012, Baltimore, Maryland, SPIE. United States 


\section{PROCEEDINGS OF SPIE}

\section{Optical Pattern Recognition XXIII}

David P. Casasent

Tien-Hsin Chao

Editors

26-27 April 2012

Baltimore, Maryland, United States

Sponsored and Published by

SPIE

Volume $\mathbf{8 3 9 8}$

Proceedings of SPIE, 0277-786X, v. 8398 
The papers included in this volume were part of the technical conference cited on the cover and title page. Papers were selected and subject to review by the editors and conference program committee. Some conference presentations may not be available for publication. The papers published in these proceedings reflect the work and thoughts of the authors and are published herein as submitted. The publisher is not responsible for the validity of the information or for any outcomes resulting from reliance thereon.

Please use the following format to cite material from this book:

Author(s), "Title of Paper," in Optical Pattern Recognition XXIII, edited by David P. Casasent, Tien-Hsin Chao, Proceedings of SPIE Vol. 8398 (SPIE, Bellingham, WA, 2012) Article CID Number.

ISSN 0277-786X

ISBN 9780819490766

Published by

SPIE

P.O. Box 10, Bellingham, Washington 98227-0010 USA

Telephone +1 3606763290 (Pacific Time) · Fax +1 3606471445

SPIE.org

Copyright () 2012, Society of Photo-Optical Instrumentation Engineers

Copying of material in this book for internal or personal use, or for the internal or personal use of specific clients, beyond the fair use provisions granted by the U.S. Copyright Law is authorized by SPIE subject to payment of copying fees. The Transactional Reporting Service base fee for this volume is $\$ 18.00$ per article (or portion thereof), which should be paid directly to the Copyright Clearance Center (CCC), 222 Rosewood Drive, Danvers, MA 01923. Payment may also be made electronically through CCC Online at copyright.com. Other copying for republication, resale, advertising or promotion, or any form of systematic or multiple reproduction of any material in this book is prohibited except with permission in writing from the publisher. The CCC fee code is 0277-786X/12/\$18.00.

Printed in the United States of America.

Publication of record for individual papers is online in the SPIE Digital Library.

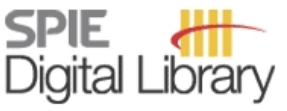

SPIEDigitalLibrary.org

Paper Numbering: Proceedings of SPIE follow an e-First publication model, with papers published first online and then in print and on CD-ROM. Papers are published as they are submitted and meet publication criteria. A unique, consistent, permanent citation identifier (CID) number is assigned to each article at the time of the first publication. Utilization of CIDs allows articles to be fully citable as soon as they are published online, and connects the same identifier to all online, print, and electronic versions of the publication. SPIE uses a six-digit CID article numbering system in which:

- The first four digits correspond to the SPIE volume number.

- The last two digits indicate publication order within the volume using a Base 36 numbering system employing both numerals and letters. These two-number sets start with 00, 01, 02, 03, 04 , $05,06,07,08,09,0 A, 0 B \ldots$. OZ, followed by 10-1Z, 20-2Z, etc.

The CID number appears on each page of the manuscript. The complete citation is used on the first page, and an abbreviated version on subsequent pages. Numbers in the index correspond to the last two digits of the six-digit CID number. 


\section{Contents}

vii Conference Committee

\section{SESSION 1 INVITED SESSION ON OPTICAL PATTERN RECOGNITION}

839802 Identification and detection of oil and oil-derived substances at the surface and subsurface levels via hyperspectral imaging (Invited Paper) [8398-01]

M. S. Alam, R. P. Gollapalli, P. Sidike, Univ. of South Alabama (United States)

839803 A self-organized learning strategy for object recognition by an embedded line of attraction (Invited Paper) [8398-02]

M.-J. Seow, BRS Labs. (United States); A. T. Alex, V. K. Asari, Univ. of Dayton (United States)

839804 A compressive sensor concept for target detection (Invited Paper) [8398-03]

A. Mahalanobis, R. Muise, Lockheed Martin Missiles and Fire Control (United States)

\section{SESSION 3 OBJECT CLASSIFICATION AND DETECTION}

839806 Optimization of support vector machine (SVM) for object classification [8398-05]

M. Scholten, California State Univ. (United States); N. Dhingra, Univ. of Michigan (United

States); T. T. Lu, T.-H. Chao, Jet Propulsion Lab. (United States)

839807 Active imaging processing technique for sensor data reconstruction and identification [8398-07]

A. Sokolnikov, Visual Solutions and Applications (United States)

839808 A computationally efficient appearance-based algorithm for geospatial object detection [8398-08]

D. Arslan, A. A. Alatan, Middle East Technical Univ. (Turkey)

\section{SESSION 3 CORRELATORS FOR OPTICAL PATTERN RECOGNITION}

839809 Towards all-numerical implementation of correlation [8398-09]

A. Alfalou, Institut Superieur de l'Electronique et du Numerique (France); C. Brosseau, Lab-STICC, CNRS, Univ. de Bretagne Occidentale (France); B.-E. Benkelfat, Institut Télécom, CNRS (France); S. Qasmi, I. Léonard, Institut Superieur de l'Electronique et du Numerique (France)

8398 OA Sensitivity of optical correlation to color change of target images [8398-10] M. Elbouz, A. Alfalou, Institut Superieur de l'Electronique et du Numerique (France); C. Brosseau, Lab-STICC, CNRS, Univ. de Bretagne Occidentale (France); M. S. Alam, Univ. of South Alabama (United States); S. Qasmi, Y. Overhani, Institut Superieur de l'Electronique et du Numerique (France) 
$8398 \mathrm{OB}$ Target tracking using nonlinear reference phase-encoded joint transform correlation [8398-11]

M. N. Islam, Farmingdale State College, SUNY (United States); V. K. Asari, Univ. of Dayton (United States); M. A. Karim, Old Dominion Univ. (United States); M. S. Alam, Univ. of South Alabama (United States)

8398 OC Optical multichannel correlators for high-speed targets detection and localization [8398-12] V. Perju, National Council for Accreditation and Attestation (Moldova); D. Casasent, Carnegie Mellon Univ. (United States)

\section{SESSION 4 CORRELATION FILTERS FOR OPTICAL PATTERN RECOGNITION}

8398 OD Improving OT-MACH filter performance for target recognition applications with the use of a Rayleigh distribution filter [8398-13]

A. Alkandri, N. Bangalore, A. Gardezi, P. Birch, R. Young, C. Chatwin, Univ. of Sussex (United Kingdom)

8398 OE Composite wavelet filters for enhanced automated target recognition [8398-14]

J. N. Chiang, Univ. of California, Los Angeles (United States); Y. Zhang, Onescreen Inc.

(United States); T. T. Lu, T.-H. Chao, Jet Propulsion Lab. (United States)

8398 OG Variants of minimum correlation energy filters: comparative study [8398-16]

N. N. Evtikhiev, D. V. Shaulskiy, E. Yu. Zlokazov, R. S. Starikov, National Research Nuclear Univ. MEPhl (Russian Federation)

\section{SESSION 5 TECHNIQUES AND APPLICATIONS}

$8398 \mathrm{OH} \quad$ Compact liquid crystal waveguide Fourier transform spectrometer for real-time gas sensing in NIR spectral band [8398-17]

T.-H. Chao, T. T. Lu, Jet Propulsion Lab. (United States); S. R. Davis, S. D. Rommel, G. Farca, B. Luey, A. Martin, M. H. Anderson, Vescent Photonics Inc. (United States)

8398 ol A secure approach for encrypting and compressing biometric information employing orthogonal code and steganography [8398-18]

M. F. Islam, George Washington Univ. (United States); M. N. Islam, Farmingdale State College, SUNY (United States)

$8398 \mathrm{0J}$ Spatial domain sharpening of color image employing bidimensional empirical mode decomposition [8398-19]

S. M. A. Bhuiyan, Univ. of South Alabama (United States); J. F. Khan, Tuskegee Univ. (United States); M. S. Alam, Univ. of South Alabama (United States)

8398 OK Automated detection of semagram-laden images using adaptive neural networks [8398-20]

P. S. Cerkez, Nova Southeastern Univ. (United States) and DCS Corp. (United States);

J. D. Cannady, Nova Southeastern Univ. (United States) 
8398 OM A new time-adaptive discrete bionic wavelet transform for enhancing speech from adverse noise environment [8398-22]

S. Palaniswamy, Bannari Amman Institute of Technology (India); P. Duraisamy, Univ. of North Texas (United States); M. S. Alam, Univ. of South Alabama (United States); X. Yuan, Univ. of North Texas (United States)

\section{POSTER SESSION}

8398 ON Design and simulation of a multiport neural network heteroassociative memory for optical pattern recognitions [8398-23]

V. Krasilenko, Vinnitsa Social Economy Institute (Ukraine); A. Lazarev, Vinnitsa National Technical Univ. (Ukraine); S. Grabovlyak, Vinnitsa Social Economy Institute (Ukraine)

839800 The investigation of the Fourier spectrum-based image complexity metrics for recognition applications [8398-24]

V. Perju, National Council for Accreditation and Attestation (Moldova); D. Casasent, Carnegie Mellon Univ. (United States)

8398 OP Hybrid optical-digital encryption system based on wavefront coding paradigm [8398-25] M. V. Konnik, The Univ. of Newcastle (Australia)

8398 OQ Development of a novel image processing method: the LPED method [8398-26] C. J. Hu, Southern Illinois Univ. Carbondale (United States) and SunnyFuture (United States)

8398 OR Using wavefront coding technique as an optical encryption system: reliability analysis and vulnerabilities assessment [8398-27]

M. V. Konnik, The Univ. of Newcastle (Australia)

Author Index 
Downloaded From: https://www.spiedigitallibrary.org/conference-proceedings-of-spie on 26 Apr 2023

Terms of Use: https://www.spiedigitallibrary.org/terms-of-use 


\title{
Conference Committee
}

\author{
Symposium Chair
}

Kevin P. Meiners, Office of the Secretary of Defense (United States)

Symposium Cochair

Kenneth R. Israel, Lockheed Martin Corporation (United States)

Conference Chairs

David P. Casasent, Carnegie Mellon University (United States)

Tien-Hsin Chao, Jet Propulsion Laboratory (United States)

Program Committee

Mohammad Showkat Alam, University of South Alabama (United States)

Don A. Gregory, The University of Alabama in Huntsville (United States)

Bahram Javidi, University of Connecticut (United States)

B. V. K. Vijaya Kumar, Carnegie Mellon University (United States)

Yunlong Sheng, Université Laval (Canada)

Robert C. Stirbl, Jet Propulsion Laboratory (United States)

Ashit Talukder, National Institute of Standards and Technology (United States)

Shizhuo Yin, The Pennsylvania State University (United States)

Rupert C. Young, University of Sussex (United Kingdom)

\section{Session Chairs}

1 Invited Session on Optical Pattern Recognition

David P. Casasent, Carnegie Mellon University (United States)

2 Object Classification and Detection

Tien-Hsin Chao, Jet Propulsion Laboratory (United States)

3 Correlators for Optical Pattern Recognition

Rupert C. Young, University of Sussex (United Kingdom)

David P. Casasent, Carnegie Mellon University (United States)

4 Correlation Filters for Optical Pattern Recognition

Ashit Talukder, National Institute of Standards and Technology (United States)

Rupert C. Young, University of Sussex (United Kingdom) 
$5 \quad$ Techniques and Applications

Mohammad Showkat Alam, University of South Alabama (United States)

Tien-Hsin Chao, Jet Propulsion Laboratory (United States) 